\title{
NATIONALISM AMONG INDIAN WOMEN IN MALAYA, 1941 - 1948
}

\author{
Dr.Syamala Nair Gopal ${ }^{1}$, PhD \\ Senior Teacher, \\ Haji Zainul Abidin Form Six College, \\ Penang, \\ Malaysia
}

\author{
Dr.Ganesan Shanmugavelu ${ }^{2}, \mathrm{PhD}$ \\ Senior Lecturer, \\ Institute of Teacher Education Ipoh Campus, \\ Malaysia
}

Article DOI: https://doi.org/10.36713/epra6063

\begin{abstract}
This study is aimed to evaluate the spirit of nationalism among Indian women in Malaya during and after the Japanese occupation between 1941 to 1948. Malaya's sustainable economic growth required improvement in terms of labour productivity. The economic growth that occurred in Malaya during the British occupation has led to an influx of immigrants from India and China in droves. Indian labour contribution in increasing Malayan economy can't be ignored. The presence of Indian women workers, although not as many as Indian male workers, can still be regarded as something significant in Malaya's economic growth. From the aspect of tradition in India, Indian women were not allowed to go out to earn a living, especially out to a foreign country. However, this situation changed due to unavoidable circumstances. The presence of Indian women in Malaya has put them in an oppressed situation and various parties have taken the opportunity to exploit their position. This had led them to be involved in movements that could take them out of the oppressed situation and the exploitation that they had to endure. Their participation in Rani of Jhansi movement had given them the courage to be involved in estate strikes soon after. The experiences gained during the Japanese occupation and involvement in the Rani of Jhansi regiment also awaken some prominent figures to actively participate in self-help organizations and politics to further enhance the status of Indian women in Malaya.
\end{abstract}

KEYWORDS : Indian, Women, Nationalism,Regiment,Labour, Estate, Strike

\section{INTRODUCTION}

The Indian migration to Malaya as a result of economic growth resulted from the British colonization has left an impact on the ethnic composition of workers in Malaya. Although the number was lower than Indian men, the recruitment of Indian women workers can still be regarded as relevant and a vital source of energy at that time.

To attract the entry of South Indians into Malaya the British government highlighted the peninsula's great wealth with the promise of benefits like accommodation and route fees. The extensive wage differences between South India and Malaya had attracted massive numbers of workers to the latter with the hope of getting better best of life for themselves and their families. Due to financial pressure faced by the Indians, the colonial government used this possibility to seek reasonablypriced labour and maintain labourers in poor working conditions. As the Malayan economy multiplied the recruitment of Indian labour became more essential.
In the beginning, male labour were favoured be it within the plantation, creation or mining sectors. Between 1844 and 1910 almost 250,000 Indian labourers were introduced into Malaya via a settlement system. As per tradition, Indian women were not allowed to go out and earn money for a living, more so working in a foreign country. Both faith and cultural practices restrained their freedom due to the fact as wives their principal roles have been to serve their husbands and their husbands' families. ${ }^{\mathrm{i}}$

In the $1890 \mathrm{~s}$, estate employers began to realize that they were too dependent on male labourers who worked on a temporary basis which resulted in a significant increase in production costs. With deteriorating political relations between the British government in India and in Malaya following their administrative separation in 1867 , there was a decline of Indian migration to the latter. This necessitate estate employers to encourage Indian workers who came to Malaya to bring their wives 
and families. The aim was to ensure labour retention. Indian women who came in at that time were regarded as "servicing agents" and "labour reproducers" to the estate community. They were also considered as low-skilled workers. This is proven by the very low wages earned by Indian female labourers at that time. They were also ineligible for any bonuses or separate meals as they were regarded as "secondary wage earner". ii

This paper will examine the struggle that Indian women had to endure during the Japanese occupation, and their participation in radical movements in Malaya especially in the Rani of Jhansi Regiment in Malaya. Soon after the fall of the Japanese occupation in Malaya and the failure of the regiment, estate labourers got involved in labour movements. Hence, the involvement of Indian women in strikes and labour protest will be given due preferences.

\section{THE EMERGENCE OF NATIONALISM AMONG INDIAN WOMEN IN MALAYA}

In the 1930s, the emergence of radical nationalism in India had given some exposure to the Indian estate labourers in Malaya. The dissemination of the nationalism idea among Indian estate labourers in Malaya was done by the Central Indian Association of Malaya (CIAM). This had led to several visits of Indian nationalist leaders to Malaya such as Pandit Jawaharlal Nehru and AK Gunalan. Their visits had strengthened their relationships and encouraged the trade union spirit among the estate labourers. ${ }^{\text {iii }}$

However, CIAM leaders and fighters mainly consisted of middle-class male leaders and no Indian women were involved in CIAM top leadership. Besides, it has been proven from interviews with several country leaders who actively involved in the independence movement, that the Indian women's involvement in radical movements only began to emerge during the Japanese occupation era. ${ }^{\text {iv }}$

The Japanese occupation period gave a sense of awareness among women in Malaya. This particular era has brought many hardships to women's life in general. The horrifying war experiences recorded in their memories and biographies show women's struggles in their daily lives. In addition, parents were worried about their daughters' safety. They even had to hide their girls or send them to live with their relatives in order to protect them from being raped, tortured or sexually exploited by the Japanese military at that time. ${ }^{v}$ Although the Japanese occupation had a profound effect on the Chinese community in Malaya, the Indians who became labourers in the estate also experienced such hardships. By the end of 1942, 18 Japanese rubber companies merged and set up
Syonan Rubber Syndicate which took over the rubber industry in Singapore and Malaya. This syndicate only allows labourers to work for only 10 to 15 days in a month. Moreover, the labourers were given a very low daily wages of almost $30 \%$ to $40 \%$ less than wages received from British colonisers. The Japanese army used a forced labour system in which Indian male labourers were forced to leave their families and were sent to work in the death railway construction from Bangkok to Rangoon. As a result, many Indian female labourers had to live alone in the estates. The Japanese army took the opportunity to harass and rape them. ${ }^{\mathrm{vi}}$

Although the Indians had to endure a series of problems during the Japanese occupation era, a positive thing that can be gained from the Japanese was fighting and striving desperately to liberate the homeland from colonisation. Addressing the slogan "Greater East Asia Co-Prosperity Sphere" and "Asia for the Asians", Japan had instilled a very deep nationalism spirit among Indians in Malaya to fight for liberation of India from the British colonisation.

Accordingly, the Indian Independent League (IIL) was established where IIL was a political organization set up by Indian nationalists around Southeast Asia in 1928. The main purpose of IIL was to oppose the British administration in India. IIL was led by Ras Behari Bose. After IIL organization began to gain attention, a military movement of the Indian National Army (INA) was established and led by Colonel Mohan Singh. By February 1942, IIL branches were located in Kedah, Perak, Selangor, Negeri Sembilan, Penang and Singapore and the membership was estimated at 84,700. By September 1942, the IIL membership increased to 120,000 while the INA army recruits were 16,000 by the end of 1942. vii

Unfortunately, due to their leadership issues and relatively weak goals, IIL and INA were getting less attention from the Indian community after 1942. After Japan appointed a highly charismatic nationalist, Subhas Chandra Bose as IIL leader, then the support from the Indians began to emerge. Subhas Chandra Bose was a radical nationalist leader and was once a Congress party leader in India. In July 1943, he became the President of IIL and Commander-In-Chief of INA. Meanwhile in October 1943, he set up an Indian provisional government known as Azad Hind. The Azad Hind government declared war on Britain and the United States and received recognition from Japan, Germany and Italy. viii The IIL organization began to receive very encouraging support from both male and female Indians in Malaya because of its noble movement regardless of caste, social class, gender, and political ideology. Interestingly, the women involvement in IIL movement can be clearly seen. Subhas Chandra Bose introduced 12 departments under IIL and 12 ministries in his provisional government. Out of 
them, a department with one ministry was dedicated for women and Lt. Col. Lakshmi Swaminathan, a 30year-old female doctor was appointed as a leader. ix

Subhas Chandra Bose's action was supported by Indian women and this led to the establishment of the Rani of Jhansi Regiment, a women's military force under INA. Indian women considered the establishment of this regiment as a form of respect for women. At the same time, he once said that the role of women was crucial in realising the country's liberation movement from the colonial grip as said during the inauguration of this regiment in 1943 in Singapore;

\section{'if women are given a chance to play their part, they will prove the equal of their brothers in fighting for their country' (Shonan Shimbun, 1943).}

The call was received by Indian women in Malaya and Singapore, but it was estimated that more than 2,000 Indian women had declared to join the unit after hearing his speech. One of the former female warriors in Rani Jhansi, Janaki Nahappan estimated that 1,000 women have joined this unit and mostly comprised educated women. Nevertheless, there were Indian female labourers who joined Rani of Jhansi's unit and fought alongside elite female fighters consisting of doctors, teachers, and nurses. The participation of women shows that there was an awareness of emancipation and the spirit of nationalism among Indian women in Malaya. The awareness of nationalism among Indian women was proved through voluntary participation of elite and grassroots women to liberate India from British colonisation. ${ }^{\mathrm{x}}$

However, many historians were uncertain of what was the real cause that led to the action of Subhas Chandra Bose. Some said it was set up to get the support from the men, some even said it was a propaganda move. Although Bose was said to be a person who cares about gender equality in engaging women to achieve Indian independence, his actions were often linked to a political agenda. There is an opinion that women's emancipation is not the primary goal of Subhas Chandra Bose, but his real aim was Indian independence. From the perspective of K.R Menon, former IIL senior officer;

'It [the RJR] was a mere puppet show. And not a single women knew how to wield a knife properly. They knew how to wield the kitchen knife, but not the knife for the battle. And they had no other source because every day this propaganda going on and asking Indian women to come and join. They are not going to fight, you know, but they are going to do other service for the army - the regular army...'(Datta, 2016)
In addition, an Indian lady pointed out that the establishment of the Rani of Jhansi regiment was a propaganda and unnecessary act. She argued that during the period, women should be helpful in matters such as nursing rather than holding weapons. ${ }^{x i}$ Another opinion pointed out that Subhas Chandra Bose's skills had attracted many women towards him and some were willing to donate their jewellery, "if the women were wearing jewellery, she took off all their jewellery and gave it to him".xii

However, this opinion had been disputed by some of the parties including women whom regarded as elites and held high positions in the regiment namely Rasammah Bhupalan. She stressed that the establishment of this regiment was to show that women should also play an important role in the homeland liberation and work together with men for that purpose. Besides, she also pointed out that when Indian men who joined the British troop saw Indian women willing to leave their families and join the battlefield for the country's future, they will be feeling guilty. xiii

According to Dr. Sahgal, the Indian community in Southeast Asia at that time was consisted of people living in disadvantages whom did not hold high positions such as labourers in rubber estates, workers in Public Works Department, clerks, and office assistants. Based on their confidence in Bose's intentions, nearly 1000 women joined this regiment to bring Indian independence. In Bose's speech, Dr. Sahgal mentioned the part when Bose stressed that women's participation in homeland freedom movement as very important. The freedom that they want to achieve is not merely the freedom of the land, but also freedom for themselves, "...now this is their chance not only to get freedom of the country but to get their own emancipation".xiv

However, all archival materials and oral history sources were only focused on only one group, namely elite women. Meanwhile, the subaltern women voices such as the Indian female labourers in the estate which covered almost $80 \%$ of the Rani of Jhansi regiment were not being given enough attention and appreciation. What was the real purpose of their participation, was it because they wanted to oppose the British occupation? As noted earlier, these subaltern Indian women consist of uneducated and unexposed people from the outside world. In this kind of situation, the nationalist ideas such as the highly educated Subhas Chandra Bose were not easily understood by these people. The real purpose of Indian women in the estate joining the regiment was to escape from the hardships faced by them in the estate. Other than that, they joined this regiment to protect themselves from several problems such as food and cloth shortages, sexual harassment, and domestic violence. The following statement is Datta's opinion (2015) on this matter; 
"that women from estates were drawn to the RJR in part to secure benefits that were beyond the reach of other women. This indicates that the estate women used the dominant nationalist to alter their own lives".

The establishment of the regiment was also to meet the needs of nurses and cooks in providing food for the independence fighters. Although initially, the regiments were given military training but they did not participate in any activity on the battlefield. According to Andaya (2017), although basically this regiment was established as the movement support, such as cooking, giving treatment, and other side works, the regiment also received military training and was involved in Burmese war. However, he also agreed with the opinion that Indian women join this regiment to escape poverty and different caste or social class discrimination when they became members of the regiment;

"The uneducated young Tamil women who left the plantations to join the INA knew little about nationalism in India, and within the regiment they still experienced the discrimination of caste and class. Nevertheless, they embraced the opportunity to escape lives of poverty and drudgery, and their example was often invoked by Bose to inspire male recruits". ${ }^{X}$

The general opinion of this regiment stated that the Indian women had been given recognition by involving in the regiment. Furthermore, it gave an opportunity to the Indian women to re-evaluate their existence in the society. The Indian woman who returned after the failure of the regiment became braver, have new thinking skills, more respected, and always crave for freedom. However, all these opinions were only suitable for Indian elite women who returned with sensational stories that can be shared to the world. On the other hand, nobody knows about what happened to Indian women in the estate. Their stories were not recorded in any historical documents on the women's struggle against colonisation. This proves that socioeconomic position also plays an important role in being recognised and rewarded.

\section{ESTATE STRIKES}

After the Second World War period, there have been some changes on the mind set of Indians in Malaya towards British authority and power. This is due to the Britain's defeat to Japan as well as INA movement activities which had slightly changed the perception of Indians in Malaya against Britain. From 1946 to 1948, Indian workers joined Chinese workers in a series of militant and organized strikes. This is because of the economic problems faced by the
Indian and Chinese labourers. In May 1947, the rubber price began to fall and decreased by 25 cents per pound. This had resulted in a 20 percent wage deduction.

Several series of strikes have taken place in rubber fields consisted of many Indian workers. There were many incidents that have proven the involvement of women in these strikes. The strike events that took place in the rubber estates in Malaya from 1946 to 1948 involved issues related to wages and socio-economic problems, such as the shortage of basic necessities provisions to the Indian labourers. Indian women had been involved in a series of strikes together with men by fighting towards higher wages as occurred in the Dublin, Kedah estate. In the estate, 800 women along with 1000 men demanded a wage increase of $\$ 1.50$ a day along with more rice supplies. The strike was also held at Sungai Tawar estate, Bedong estate, and Sungai Toh Pawang estate in Kedah ${ }^{x v i}$.

Other than the wage problems, Indian women were also involved in strikes related to sexual harassment. For example, on October 28, 1946, 45 men and 28 women launched a strike at the Sussex estate, Teluk Anson, Perak. The aim of the strike was to protest against the behaviour of an estate clerk who disrupted female workers and they asked the worker to be fired. The same incident occurred in the Gapis estate, where female labourers protested against the estate conductor who disturbed women in the estate. ${ }^{x i i}$. Interestingly, female labourers started to act aggressively and courageously during their opposition. In other incident which occurred in Bukit Sembilan estate, Kedah on February 17, 1947, about 66 workers were arrested and 21 were wounded, including women. During the battle, Kedah police chief, A .C Maxwell suffered head injuries due to being hit with a stick by a woman. The incident occurred when the police entered the estate to arrest a labourer named Balaiah who allegedly seized a lorry owned by the estate management. In the arresting process, other labourers including women and children armed with logs, sticks, and hot water to prevent the action of the polices. Besides, there were a group of women who have been prepared with pepper powder in their hands and waited for the police arrival at the front position. ${ }^{\text {xviii }}$.

The series of protests that have taken place in some of these estates has led to the emergence of a relatively well-known movement among Indian community during late 1940s. The movement was called the Thondar Padai movement, also known as the Youth Corps, an established militant group to protect the interests of Indian labourers. ${ }^{\mathrm{xix}}$. Thondar Padai's members consisted of INA former soldiers. There was evidence showing women who had been Rani of Jhansi regiment members during the Japanese occupation whom joined this movement. The women's 'wing' in Thondar Padai was assigned 
to protect the interests of women workers. The Thondar Padai movement attracted labourers in the estates, particularly aged between 15 and 30 years old. The aim of the movement was to solve the economic and social problems experienced by Indian labourers at that time. They were involved in social reformations such as stopping drinking habits, improving health status, and solving domestic problems. There was also an incident that shows Thondar Padai's members used violence in achieving their goals. For instance, they punished labourers who were unwilling to stop drinking toddy by tying them to the trees.

"the present troubles arose through the activities of the Youth Corps which had been going around beating up conductors, tying workers up for drinking toddy and trespassing of estates against the wishes and often without the knowledge of managers". (The Straits Times, 7 Mac, 1947)

In one of incidents where they tied the labourers for four hours, five labourers were arrested by the police and two of them were women named Ananthayn and Manidammal. ${ }^{x x}$. The violent action taken by this movement has led the British to worry and they began to link this movement to the Communist Party of Malaya. As a result, the British took decisive action especially in resolving the strike events that was allegedly initiated by the Thondar Padai movement. For example on February 28, 1947, British security forces dispersed a group of women and children who were picketing in front of a toddy shop in the Bedong estate, Kedah. ${ }^{x x i}$ In this rally, women labour was only armed with hot water, wood, stone and pepper powder when dealing with polices armed with pistols, bayonets, rifles and batons. In the incident, a labourer died due to being beaten by a baton and nine other people were injured.xxii. Similarly, a strike occurred in Bukit Sembilan on March 3, 1947 and Dublin's estate on April 28, 1947, all linked to the violent Thondar Padai movement. In an investigation conducted by Indian Government Agency, SK Chettur, following an incident in Bukit Sembilan, British had taken an unjust action where many women were hit by security forces and two women were raped by British security forces while in custody. Nevertheless, the colonial government stressed that violence has to be taken in order to ease the uncontrolled situation. ${ }^{x x i i i}$. Many followers of this movement had been arrested and sent back to India meanwhile Thondar Padai movement was banned in 1948.

The involvement of Indian women in trade unions was less active than women of other races. This is because of the conservative view of Indian society that discourages women from engaging in social activities. Furthermore, major issues of Indian women such as sexual harassment, workplace discrimination as well as childcare issues had not gained the attention of the trade unions at the time. ${ }^{\text {xiv }}$ The trade unions set up in small estates usually belong to Tamil people in the estate. At the same time, they functioned as a panchayat (court of justice) to solve problems in the estate including problems involving women. In 1946, a rape incident of a 16year-old young woman by an estate foreman was discussed by a union like this in one Kedah estate. The foreman was only fined $\$ 50$ (reduced to $\$ 25$ after appeal) to be donated to a temple in the estate. $^{\mathrm{xxv}}$ It is clear here that serious cases such as rape which should be reported to the police have been underestimated by the unions in the estate.

Hence, it is arguable that labour struggles among Indians became stronger due to the escalating nationalist spirit after the increasing issue of workers' exploitation in Malaya. Their affiliation with Chinese labourers was a combination that gives confidence to Indian female labourers to participate and voice their needs. Besides, political awareness among them also began to emerge and raise their desire to fight for their rights in Malaya.

\section{CONCLUSION}

Conservative views are often thrown over the women role among the Indian society in Malaysia. Although they actively participated in gaining income and supporting their family needs, they were still considered as a dependent group towards men. They were always protected and separated from the outside world. A Tamil proverb related to this context is 'aanai potri vala, pennai adithu vala' which means 'love the son, hit the daughter'.

Exposure and influence of the nationalism movement from other countries such as India and the involvement of Malay and Chinese women in social activism, labour struggles and political consciousness inherent in them have been profoundly inspiring to Indian women. This has made them aware of the importance of education and the equality rights between men and women in the society. The injustice, labour exploitation and awful experience during the Japanese occupation have opened their minds and thoughts to be together with women of other races in voicing their rights and interests.

The personal experience and awareness of nationalism among women has led them to make decisions in politics as has been done by Indian female figures such as Janaki Athi Nahappan and Devaki Krishnan. In addition, the experiences gained during the Japanese occupation and involvement in the Rani of Jhansi regiment also awaken some prominent figures such as Rasammah Bhupalan to actively participate in self-help organizations to further enhance the status of Indian women in Malaysia. Finally, the socio-economic situation and political consciousness of Indian women in Malaysia received more attention after the 1960 s period. 


\section{REFERENCES}

${ }^{i}$ Dancz, Virginia H. Women and party politics in Peninsular Malaysia. Oxford University Press, 1987.; pg 57-61. Until 1920 the number of Indian male labourers who came to Malaya through the kangani system was more than their female counterparts. Even after 1920, Indian male labourers still accounted for almost 70 percent of the number of the workforce who came to Malaya. Most women who were brought in from South India comprised of Tamils, Telugus, and Malayalis but a small number comprising Sikhs, Punjabi Hindus, Bengalis, and Gujeratis originated from north India. Almost $80 \%$ of these women were Tamils. See Sandhu, Kernial Singh. Indians in Malaya: Some aspects of their immigration and settlement (1786-1957). Cambridge University Press, 2010. Cambridge: Cambridge University Press; pg 71.

ii Datta, Arunima. "'Immorality', Nationalism and the Colonial State in British Malaya: Indian 'coolie'women's intimate lives as ideological battleground." Women's History Review 25, no. 4 (2016): 584-601.

${ }^{i i i}$ Stenson, Michael. Class, race, and colonialism in West Malaysia. UBC Press, 2011. The issues that had been raised by CIAM involve toddy drinking habits among Indian estate workers, land and health problems, as well as education and childcare issues in the estate. In addition, CIAM also highlighted the issue of equal wages among the estate Indian workers. The Straits Times, February 2, 1940. ${ }^{i v}$ Sandhu, Kernial Singh. Indians in Malaya; p.92

${ }^{v}$ Musa, Mahani. "Malayan Women during the Japanese Occupation." Journal of the Malaysian Branch of the Royal Asiatic Society 89, no. 2 (2016): 101-124.

vi Datta, Arunima. "Immorality', Nationalism and the Colonial State in British Malaya;584-601. According to Jain (1970), newly married couples were separated, the husbands were sent to work at the railway construction while the wives were made mistress. Some of the women were being locked in the room, undressed, tied to the chair and beaten by them. See Jain, Ravindra Kumar. South Indians on the plantation frontier in Malaya. Kuala Lumpur: University of Malaya Press, 1970

${ }^{v i i}$ Dancz, Virginia H. Women and party politics; p.66 \& Datta, Arunima. "'Immorality', Nationalism and the Colonial State in British Malaya;584-601

viii Hills, Carol, and Daniel C. Silverman. "Nationalism and feminism in late colonial India: The Rani of Jhansi Regiment, 1943-1945." Modern Asian Studies 27, no. 4 (1993): 741-760.

${ }^{i x}$ For further detail please see Ramachandran, S. and Shanmugam, B., 1995. Plight of plantation workers in Malaysia: defeated by definitions. Asian Survey, 35(4), pp.394-407. Lebra, Joyce. Women Against the Raj: The Rani of Jhansi Regiment. Institute of Southeast Asian Studies, 2008., Datta, Arunima. "Social Memory and Indian Women from Malaya and Singapore in the Rani of Jhansi Regiment." Journal of the Malaysian Branch of the Royal Asiatic Society 88, no. 2 (2015): 77-103 \& Dancz, Virginia H. Women and party politics; p.90

${ }^{x}$ Ruhana, Padzil. "Perjuangan wanita dalam aktivisme sosial dan nasionalisme di Tanah Melayu, 19291957/Ruhana Padzil." PhD diss., University of Malaya, 2017.
${ }^{x i}$ Interview with Mrs Vilasini Perumbulavil, Oral History Interviews, National Archives of Singapore, Accession No 002437

xii Interview with Seva Singh, Oral History Interviews, National Archives of Singapore, Accession No 000418.

xiii Gopinath, Aruna. Footprints on the Sands of Time: Rasammah Bhupalan: A Life of Purpose. Arkib Negara Malaysia, 2007.

${ }^{\text {xiv }}$ Interview with Lakshmi, S (Dr), Oral History Interviews, National Archives of Singapore, Accession No 001182

${ }^{x v}$ Andaya, Barbara Watson, and Leonard Y. Andaya. A history of Malaysia. Macmillan International Higher Education, 2016.

${ }^{x v i}$ The Straits Times, February 27, 1947

xvii Indian Daily Mail, September 14, 1946

xviii The Straits Times, March 4, 1947

xix CO 537/3752: Malayan Security Service, Political Intelligence Journal.

${ }^{x x}$ The Straits Times, April 21, 1947.

${ }^{x x i}$ Indian Daily Mail, March 6, 1947.

xxii CO537 / 2173: Labour Situation Unrest among Estate Labour.

xxiii Malaya Tribune, March 20, 1947.

${ }^{x x i v}$ Todd, Trish, and K. S. Jomo. Trade unions and the state in Peninsular Malaysia. Oxford University Press, 1994.

${ }^{x x}$ Malayan Union: Annual Report of Labour Department, 1946 